DOI: https://doi.org/10.24127/ajpm.v10i3.4050

\title{
PENGEMBANGAN MEDIA PEMBELAJARAN BERBASIS APLIKASI ANDROID PADA MATERI TURUNAN FUNGSI ALJABAR
}

\author{
Destiniar $^{1}$, Rohana $^{2^{*}}$, Hijir Ardiansyah ${ }^{3}$ \\ ${ }^{1,2 * 3}$ Pendidikan Matematika, Universitas PGRI, Palembang, Indonesia \\ *Corresponding author. \\ E-mail: destiniar@univpgri-palembang.ac.id ${ }^{1)}$ \\ rohana@univpgri-palembang.ac.id $^{\left.2^{*}\right)}$ \\ hijir.ardiansyah@gmail.com $^{3}$
}

Received 25 July 2021; Received in revised form 12 September 2021; Accepted 15 September 2021

\begin{abstract}
Abstrak
Jenis penelitian ini adalah Research and Development (R\&D). Penelitian ini menggunakan metode penelitian ADDIE yang terdiri dari lima tahapan yaitu Analysis, Design, Development, Implementation, dan Evaluation. Tujuan dari penelitian ini adalah untuk mengembangkan media pembelajaran berbasis aplikasi android yang valid, praktis, dan efektif. Objek dalam penelitian ini adalah pengembangan media pembelajaran berbasis aplikasi android pada materi turunan fungsi aljabar untuk siswa kelas XI SMA. Subjek dalam penelitian ini ialah peserta didik kelas XI di SMA Negeri 2 Kikim Selatan. Teknik pengumpulan data yang digunakan yaitu walktrough, angket respon peserta didik, dan tes hasil belajar. Tingkat kevalidan yang dinilai oleh validator terdiri dari tiga dosen dan satu pendidik dengan aspek yang dinilai kualitas isi dan tujuan, kualitas intruksional, dan kualitas teknis dinyatakan valid menurut validator. Tingkat kepraktisan setelah diuji cobakan kepada peserta didik mendapat skor 82,9\% sehingga dikategorikan sangat praktis. dan juga berdasarkan tes hasil belajar peserta didik dengan menggunakan media pembelajaran berbasis aplikasi android memperoleh skor 95\% dengan kategori sangat efektif. Dengan demikian dapat disimpulkan bahwa media pembelajaran berbasis aplikasi android yang telah dikembangkan valid, sangat praktis dan sangat efektif.
\end{abstract}

Kata Kunci: Aplikasi android; turunan fungsi aljabar.

\begin{abstract}
This type of research is Research and Development $(R \& D)$. This study uses the ADDIE research method which consists of five stages, namely Analysis, Design, Development, Implementation, and Evaluation. The purpose of this research is to develop a valid, practical, and effective learning media based on android applications. The object of this research is the development of learning media based on android applications on the material derived from algebraic functions for class XI high school students. The subjects in this study were students of class XI at SMA Negeri 2 Kikim Selatan. Data collection techniques used are walkthrough, student response questionnaires, and learning outcomes tests. The level of validity assessed by the validator consisted of three lecturers and one educator with aspects assessed for the quality of content and objectives, instructional quality, and technical quality declared valid according to the validator. The level of practicality after being tested on students got a score of $82.9 \%$ so it was categorized as very practical. and also based on the test of student learning outcomes using learning media based on the android application, it obtained a score of $95 \%$ with a very effective category. Thus it can be concluded that the android application-based learning media that has been developed is valid, very practical and very effective.
\end{abstract}

Keywords: Android application; derivatives of algebraic functions.

This is an open access article under the Creative Commons Attribution 4.0 International License 
DOI: https://doi.org/10.24127/ajpm.v10i3.4050

\section{PENDAHULUAN}

(Siagian, 2016) mengatakan bahwa matematika mempunyai peranan yang sangat dibutuhkan bagi ilmu yang lain, terutama sains dan teknologi. Sehingga, peserta didik dituntut untuk menguasai materi matematika. Namun kenyataannya hasil belajar matematika peserta didik rendah (Wedekaningsih, Koeswati, \& Giarti, 2019).

Berdasarkan hasil kajian didapatkan bahwa (Nuryatni, 2019) mengatakan media pembelajaran PowerPoint dapat meningkatkan hasil belajar matematika. (Lubis, 2012) juga mengatakan bahwa media pembelajaran dengan Microsoft PowerPoint dapat meningkatkan hasil belajar matematika siswa. Penggunaan media pembelajaran PowerPoint membutuhkan perangkat tambahan berupa alat atau fasilitas yang mendukung seperti laptop, proyektor, dan lain-lain. Berdasarkan hasil wawancara dengan guru di SMA N 2 Kikim Selatan bahwa laptop dan proyektor disekolah masih sedikit, tetapi peserta didik memiliki smartphone android dengan rincian dalam 1 kelas yang terdiri dari 30 peserta didik ada 28 peserta didik yang memiliki smartphone android atau sekitar 93,3\%. Hal ini sejalan dengan sejalan dengan (Muflih, Hamzah, \& Purniawan , 2017) mengatakan bahwa siswa senang menggunakan Smartphone dari pada mengobrol dengan teman-temannya. Artinya ada ketergantungan peserta didik terhadap smartphone android.

Berdasarkan permasalahan di atas, ingin memaksimalkan peran Smartphone android agar dapat dimanfaatkan dalam proses pembelajar-an. Hal ini sejalan dengan (Rohman, 2018) mengatakan bahwa media pembelajaran berbasis android efektif dalam meningkatkan hasil belajar matematika siswa. (Karim \& Savitri, 2020) mengata kan bahwa media pembelajaran berbasis android dinyatakan layak untuk dimplementasikan dalam proses belajar peserta didik. Namun dari beberapa penelitian tersebut belum ditemukan media pembelajaran berbasis android pada materi turunan fungsi aljabar. Berdasarkan hal tersebut di atas, perlu dikembangkan media pembelajaran berbasis aplikasi android materi turunan fungsi aljabar.

Penelitian ini bertujuan untuk menghasilkan media pembelajaran berbasis aplikasi android pada materi turunan fungsi aljabar untuk siswa kelas XI yang valid, praktis, dan efektif. Dalam mengembangkan media pembelajaran berbasis aplikasi android, tidak perlu memiliki kemampuan pemrograman khusus. Sehingga siapa saja (guru) bisa melakukan pengembangan media pembelajaran berbasis aplikasi android. Adapun aplikasi pembantu dalam pengembangan ini adalah $I$ Spring dan Website 2 APK builder. Sumargono (Handayani \& Rahayu, 2020) mengatakan bahwa I-Spring mampu membuat produk yang dapat mendukung program e-learning yang efektif melalui integrase dengan $I$ Spring Quizmaker dan I-Spring Kinestics. Website 2 APK Builder adalah software yang digunakan untuk membuat aplikasi android dari webesite atau HTML 5. Pembuatan media pembelajaran dalam penelitian ini menggunakan Microsoft PowerPoint yang kemudian diup-gread dengan aplikasi I-Spring kedalam format HTML 5. Langkah selanjutnya mengubah HTML 5 menjadi aplikasi android dengan menggunakan software Website 2 APK Builder. Setelah diubah tinggal diinstal menggunakan smartphone android baru bisa dioperasikan. 
DOI: https://doi.org/10.24127/ajpm.v10i3.4050

\section{METODE PENELITIAN}

Penelitian ini merupakan jenis penelitian dan pengembangan atau research and development. Penelitian ini dilaksanakan di SMA Negeri 2 Kikim Selatan Kabupaten Lahat. Untuk memperoleh pengembangan yang berkualitas diperlukan penilaian media. Berdasarkan kriteria kualitas hasil penelitian pengembangan yang dikemukakan oleh Van De Akker dan Nieveen (Wardiyanto \& Yundra, 2019) menyatakan bahwa dalam penelitian pengembangan media pembelajaran diperlukan kriteria kualitas yaitu kevalidan (validity), kepraktisan (practically), dan keefektifan (effectiveness).

Model pengembangan ADDIE memiliki lima tahapan (Tegeh, Jampel, \& Pudjawan , 2014) yaitu: tahap analisis (analysis), tahap perancangan (designi), tahap pengembangan (development), tahap uji coba (implementation), dan tahap evaluasi (evaluation). Tahap analisis meliputi analisis kebutuhan, analisis kurikulum, dan analisis media. Tahap perancangan meliputi pembuatan desain awal media pembelajaran berbasis aplikasi android yang disebut dengan storyboard 1. Tahap pengembangan meliputi pembuatan media menjadi berdasarkan storyboard 1 selanjutnya memvalidasi media kepada validator untuk mengetahui apakah media sudah valid atau belum. Tahap uji coba meliputi pengujian media pembelajaran kepada peserta didik dalam proses pembelajaran. tahap evaluasi meliputi proses menevaluasi data angket respon peserta didik dan data soal tes hasil belajar peserta didik untuk mengetahui tingkat keparktisan dan keefektifan media pembelajaran.

Instrument pengumpulan data dalam penelitian ini menggunakan Walktrough, angket respon peserta didik, dan soal tes hasil belajar peserta didik. Walktrough merupakan lembar validasi ahli berupa angket terbuka untuk memvalidasi media pembelajaran kepada validator. Adapun kisi-kisi angket validasi disajikan pada Tabel 1.

Tabel 1 Kisi-kisi angket validasi

\begin{tabular}{cc}
\hline Aspek Yang Dinilai & No.Butir \\
\hline Kualitas isi dan tujuan & 1,2 \\
Kualitas intruksonal & 3,4 \\
Kualitas Teknis & 5,6 \\
\hline
\end{tabular}

Sumber: (Firdaus, 2019)

Angket respon peserta didik berupa angket tertutup yang diberikan kepada peserta didik setelah melakukan uji coba kepada peserta didik. Hal ini dilakukan untuk mengetahui tingkat keparaktisan media pembelajaran. angket respon peserta didik menggukan skala likert dengan penilaian 1-5. Adapun kisi-kisi angket respon peserta didik dapat dilihat pada Tabel 2 .

Tabel 2 Kisi-kisi angket respon peserta didik

\begin{tabular}{lcc}
\hline \multicolumn{1}{c}{ Aspek } & \multicolumn{2}{c}{ No. Butir } \\
\cline { 2 - 3 } & $(+)$ & $(-)$ \\
\hline Kemenarikan media & 1,3 & $2,4,6$ \\
Ketertarikan siswa & $6,7,9$ & 8,10 \\
terhadap media dan & & \\
materi & & \\
Motivasi & $11,12,15$ & 13,14 \\
Kemudahan & $17,18,20$ & 16,19 \\
\hline
\end{tabular}

Sumber: (Firdaus, 2019)

Soal tes hasil belajar peserta didik berupa soal tes pilihan ganda yang diberikan kepada peserta didik setelah proses uji coba dilaksanakan. Hal ini untuk mengetahui apakah media pembelajaran efektif dalam proses pembelajaran atau tidak.

Teknik analisis data yang dilakukan pada penelitian ini adalah analisis kevalidan yang dilakukan dengan analisis deskriptif, analisis kepraktisan media pembelajaran meng- 
gunakan analisis kuantitatif dengan rumus (1), selanjutnya analisis keefektifan dilakukan dengan rumus (2).

$$
\mathrm{K}=\frac{f}{N \times 1 \times R} \times 100 \%
$$

Sumber: (Riduwan, 2011)

Keterangan:

$\mathrm{K}=$ Persentase nilai akhir

$f=$ Keseluruhan jawaban responden

$N=$ Skor tertinggi dalam angket

$\mathrm{R}=$ Jumlah responden

$$
P=\frac{P_{a}}{P_{b}} x 100 \%
$$

Sumber: (Ariskasari \& Pratiwi, 2019) Keterangan:

$P=$ Persentase ketuntasan belajar siswa

$P_{a}=$ Jumlah Siswa yang Tuntas

$P_{b}=$ Jumlah Seluruh Siswa

Setelah diperoleh hasil dari dari analisis kepraktisan produk, kemudian dikategorikan sesuai dengan kriteria pada Tabel 3. Sedangkan untuk hasil analisis keefektifan dikategorikan sesuai dengan kriteria pada Tabel 4.

Tabel 3 Kategori nilai kepraktisan

\begin{tabular}{cc}
\hline Nilai & Kategori \\
\hline $0 \%-20 \%$ & Sangat tidak Praktis \\
$21 \%-40 \%$ & Tidak Praktis \\
$41 \%-60 \%$ & Cukup Praktis \\
$61 \%-80 \%$ & Praktis \\
$81 \%-100 \%$ & Sangat Praktis \\
\hline
\end{tabular}

Sumber: (Riduwan, 2011)

Tabel 4 Kriteria Penilaian Keefektifan

\begin{tabular}{cc}
\hline Persentase (\%) & Kriteria \\
\hline $\mathrm{P} \leq 20$ & Tidak Efektif \\
$20<\mathrm{P} \leq 40$ & Kurang Efektif \\
$40<\mathrm{P} \leq 60$ & Cukup Efektif \\
$60<\mathrm{P} \leq 80$ & Efektif \\
$80<\mathrm{P} \leq 100$ & Sangat Efektif \\
\hline
\end{tabular}

Sumber: (Ariskasari \& Pratiwi, 2019)

\section{HASIL DAN PEMBAHASAN \\ Tahap Analisis (Analysis)}

Pada tahap analisis dilakukan proes analisis kebutuhan, analisis kurikulum, dan analisis media. Kemudian diperoleh hasil bahwa berdasarkan analisis kebutuhan peserta didik saat ini adalah media pembelajaran berbasis aplikasi android. Kurikulum yang digunakan di kelas XI SMA Negeri 2 Kikim Selatan adalah Kurikulum 2013. Turunan fungsi aljabar adalah materi wajib yang dipelajari pada kelas XI Semester genap. Adapun kompetensi dasar pada silabus kelas XI materi turunan fungsi aljabar yaitu: 1) Menjelaskan sifat-sifat turunan fungsi aljabar dan menentukan turunan fungsi aljabar menggunakan definisi atau sifat-sifat turunan fungsi; 2) menyelesaikan masalah yang berkaitan dengan turunan fungsi aljabar.

Berdasarkan analisis media yang dibutuhkan dalam pembuatan media pembelajaran berbasis aplikasi android ialah Microscoft PowerPoint untuk membuat tampilan dasar dari media, $I$ Spring Suite 9 untuk membuat tampilan materi dan kuiz menjadi lebih menarik dan website 2 apk builder untuk mengubah media pembelajaran menjadi aplikasi android yang nantinya bisa di akses melalui smartphone android.

\section{Tahap Perancangan (Design)}

Pada tahap perancangan, dilakukan proses pembuatan desain awal media pembelajaran yang disebebut dengan storyboard. Storyboard ialah rancangan atau gambaran awal tentang media pembelajaran yang akan dibuat. Adapun storyboard yang dibuat meliputi: halaman awal, halaman menu, petunjuk penggunaan, $\mathrm{KD}, \mathrm{KI}$ dan tujuan pembelajaran, materi, halaman awal quiz, halaman identitas peserta didik, dan halaman soal quiz. 
DOI: https://doi.org/10.24127/ajpm.v10i3.4050

Dalam pembuatan media pembelajaran ditambahkan juga music pengiring atau backsound sehingga media pembelajaran lebih menarik. Media juga dilengkapi dengan video pembelajaran yang dapat memperjelas atau memberikan penguatan pemahaman materi kepada peserta didik.

\section{Hasil Tahap Pengembangan (Development)}

1. Membuat Aplikasi Andoid

Setelah proses pembuatan storyboard selesai, tahap selanjunya adalah pembuatan media pembelajaran dengan Ms. PowerPoint berdasarkan dengan storyboard yang sudah dibuat. Hasil dari pembuatan dengan Ms. PowerPoint ini akan disebut dengan Prototype 1. Setelah pembuatan Prototype 1 dengan PowerPoint selesai, selanjutnya file dipublish kedalam bentuk HTML5. Adapun hasil dari prototype 1 sebagai berikut:

a. Halaman awal atau tampilan awal pada media pembelajaran. pada menu terdapat logo Universitas, gambar animasi, nama aplikasi, dan tombol play untuk memulai aplikasi seperti yang terlihat pada Gambar 1 .

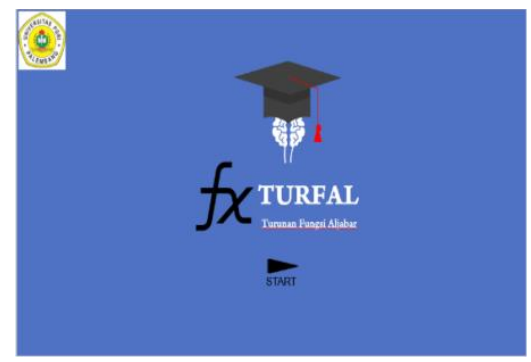

Gambar 1. Halaman awal

b. Halaman menu utama berisi sub menu yang ada didalam media pembelajaran. Halaman ini berisi daftar menu yang bisa dipilih oleh pengguna. Halaman ini juga terdapat gambar animasi seperti yang terlihat pada Gambar 2.

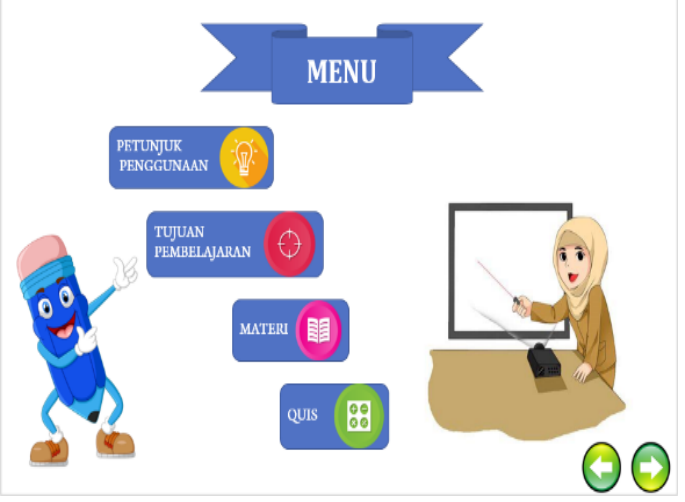

Gambar 2. Menu utama

c. Halaman ini berisi kompetensi dasar, indikator pencapaian kompetensi, dan tujuan pembelajaran yang akan dicapai seperti yang terlihat pada Gambar 3.

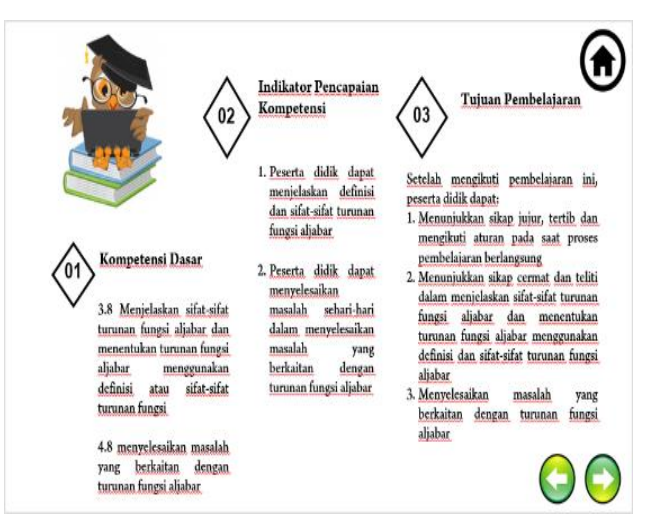

Gambar 3. KD, KI dan tujuan

d. Halaman petunjuk penggunaan berisi beberapa petunjuk dan informasi untuk pengoperasian media pembelajaran seperti yang terlihat pada Gambar 4.

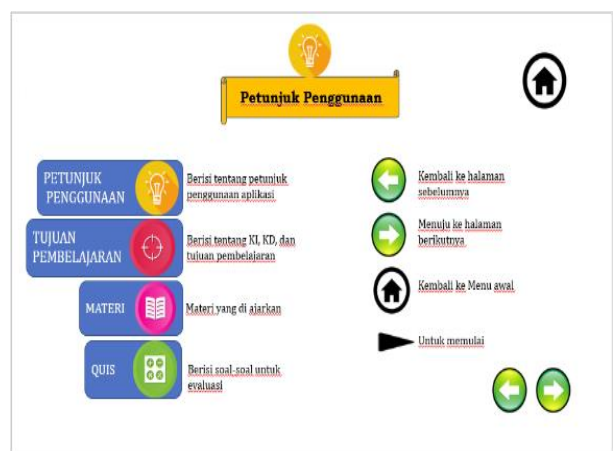

Gambar 4. Petunjuk penggunaan 
e. Halaman materi berisi materi tentang persamaan turunan fungsi aljabar. Terdapat juga video pembelajaran yang dapat membantu peserta didik dalam belajar seperti yang terlihat pada Gambar 5.

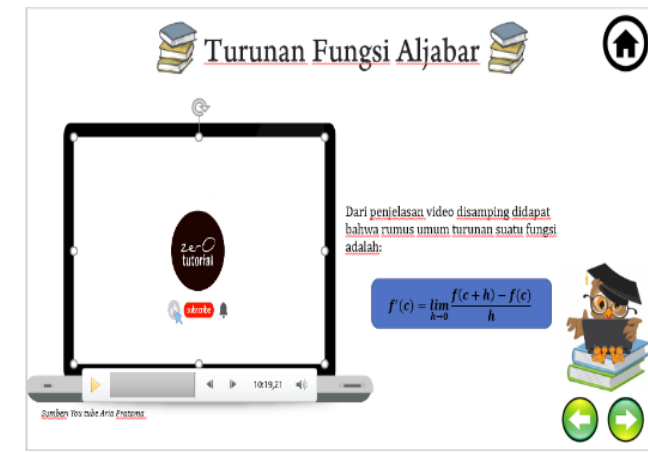

Gambar 5. Halaman materi

f. Halaman materi berisi sifat-sifat turunanan fungsi aljabar dan contoh soal pembahasannya seperti yang terlihat pada Gambar 6 .

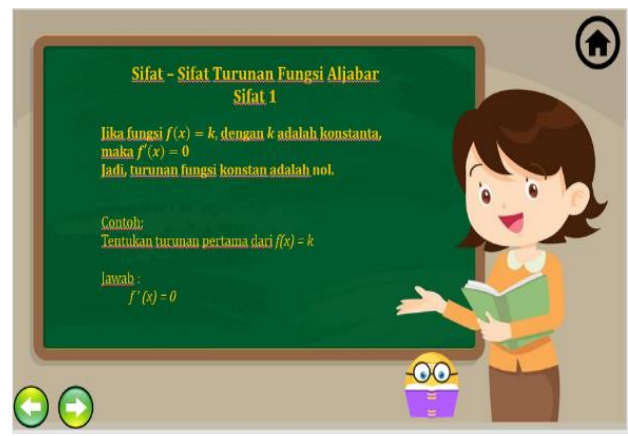

Gambar 6. Halaman materi

g. Halaman awal sebelum memulai quiz seperti yang terlihat pada Gambar 7 .

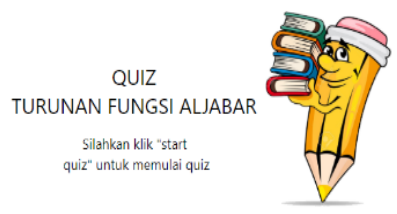

Gambar 7. Halaman awal quiz h. Halaman ini berisi data identitas peserta didik yang harus diisi sebelum menjawab soal quiz seperti yang terlihat pada Gambar 8 .

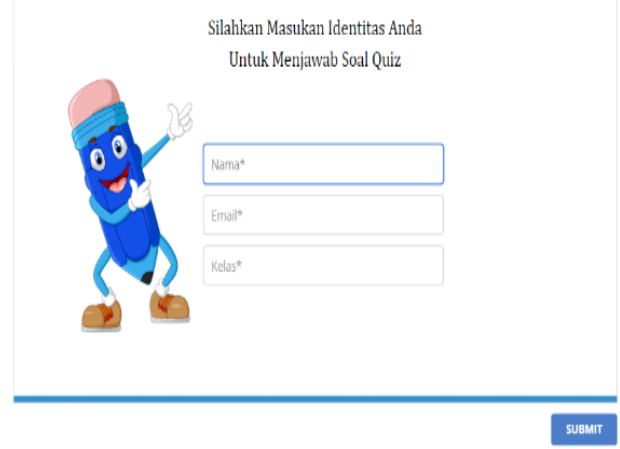

Gambar 8. Halaman identitas

i. Halaman soal quiz, quiz berupa soal pilihan ganda dimana peserta didik tinggal mengklik jawaban yang menurut mereka benar seperti yang terlihat pada Gambar 9.

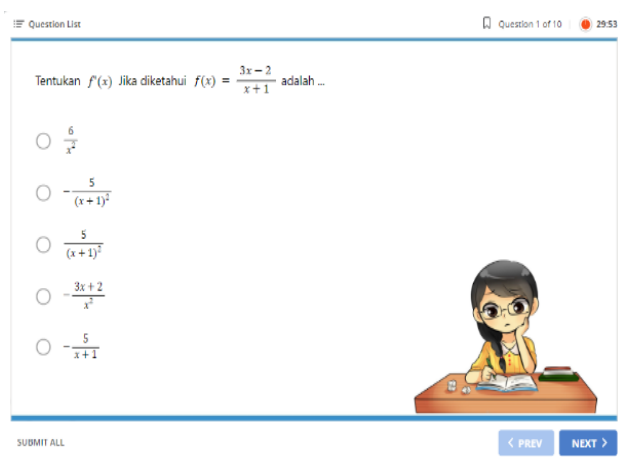

Gambar 9. Halaman soal quiz

Selanjutnya mengubah file prototype 1 yang berupa file HTML5 menjadi aplikasi yang bisa diakses melalui android. Dalam proses pembuatan media pembelajaran berbasis aplikasi android ini, aplikasi bantuan yang digunakan yaitu website 2 Apk Builder. Website 2 Apk Builder ini sangat mudah untuk digunakan jadi tidak perlu memiliki kemampuan pemrograman yang bagus siapa saja bisa menggunakannya asalkan dia biasa menggunakan laptop. karena dalam 
pembuatan media pembelajaran berbasis aplikasi android ini hanya terdiri dari 6 langkah. Adapun proses pembuatan aplikasi nya sebagai berikut:

1. Pilih Local HTML Website, itu karena file protype 1 yang sudah kita publish adalah bentuk file HTML 5.

2. Kemudian memasukkan nama aplikasi "TURFAL" pada kolom App Title

3. Memilih tempat penyimpanan luaran jika aplikasi sudah selesai dibuat

4. Memasukkan logo untuk aplikasi TURFAL

5. Masukkan file mentah aplikasi media yang sudah dipublish kedalam bentuk file HTML.

6. Klik Generate Apk, setelah itu tunggu beberapa menit dan aplikasi sudah selesai dibuat. Selanjutnya, file yang sudah di buat dari website 2 apk builder tersebut diinstal di android dan akan menjadi aplikasi android. Adapun icon media pembelajaran nya dapat dilihat pada Gambar 10 .

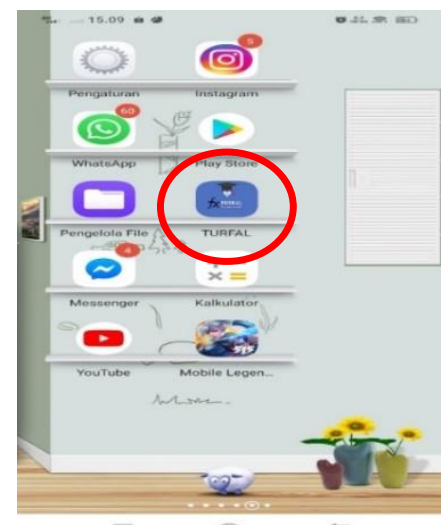

Gambar 10. Icon media pembelajaran pada smartphone android

2. Memvalidasikan Aplikasi Android

Setelah pembuatan media pembelajaran berbasis aplikasi android (prototype 1) selesai, tahap selanjutnya yaitu proses validasi oleh ahli atau pakar. Validasi aplikasi dilakukan kepada 4 pakar atau ahli yang terdiri dari 3 Dosen dan 1 Pendidik untuk melakukan penilaian terhadap aplikasi yang dibuat. Memberikan angket validasi dalam bentuk angket terbuka kepada validator untuk memberikan penilaiannya. Hasil validasi dari semua validator tersebut dapat disimpulkan bahwa secara keseluruhan baik dari kualitas dan isi tujuan, kualitas intruksional, dan kualitas teknis semuanya sudah baik tetapi masih ada yang harus di perbaiki atau direvisi. Selanjutnya langsung melakukan revisi sesuai dengan komentar dan saran dari validator. Adapun revisi yang dilakukan sesuai saran dan komentar dari validator adalah sebagai berikut:

1) Perbaikan kata-kata yang tidak sesuai dengan EYD

2) Penambahan Pembahasan contoh soal yang tidak ada seperti yang terlihat pada Gambar 11.

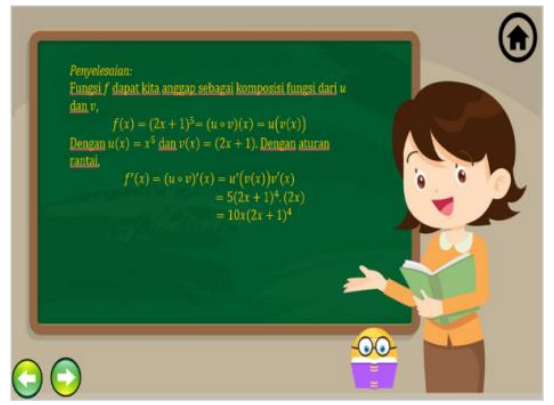

Gambar 11. Setelah revisi

3) Penambahan contoh soal dan pembahasan untuk materi yang sulit. Untuk lebih jelasnya dapat dilihat pada Gambar 12.

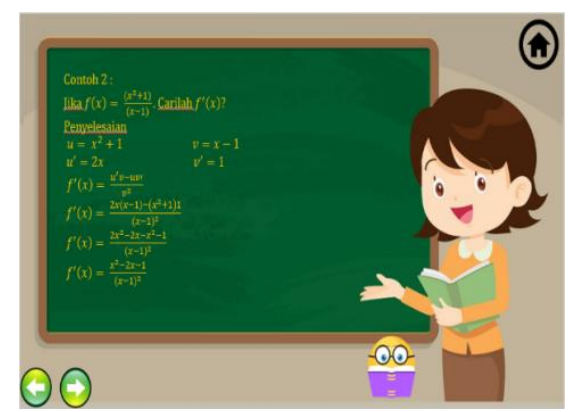

Gambar 12. Setelah revisi 
4) Menambahkan contoh soal dan pembahasan turunan fungsi aljabar dalam kehidupan sehari-hari seperti yang terlihat pada Gambar 13.

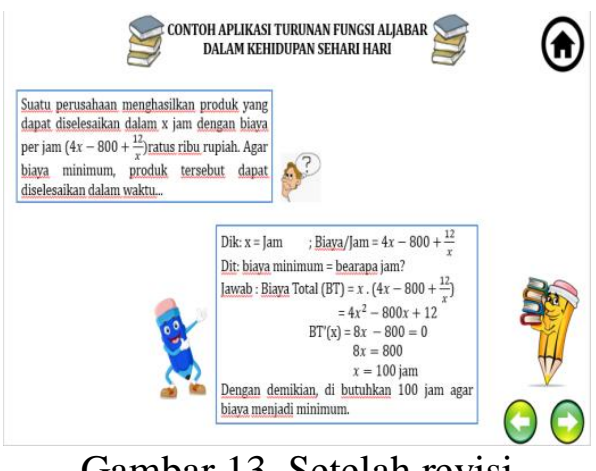

Gambar 13. Setelah revisi

5) Menghilangkan tombol yang tidak memiliki fungsi seperti tampak pada Gambar 14.

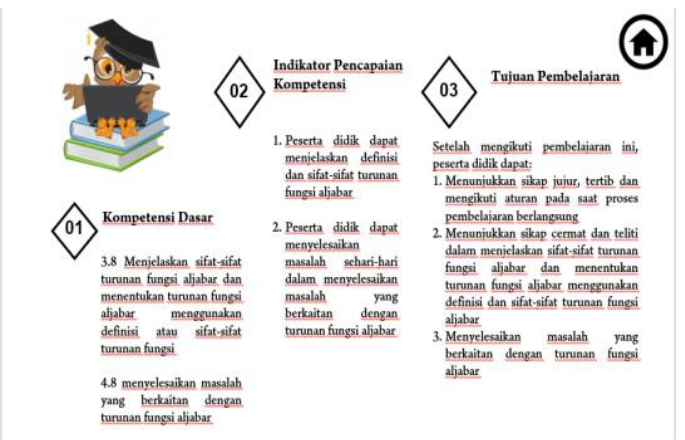

Gambar 14. Setelah revisi

Setelah melakukan revisi, selanjutnya melakukan validasi kembali kepada validator. Tujuan validasi kembali ialah untuk melihat apakah produk yang telah direvisi tersebut valid untuk digunakan atau belum. Dari hasil validasi kedua yang dilakukan, validator memberikan penilaian yang baik. Hal ini dilihat dari hasil angket penilaian validator mulai dari kualitias dan isi tujuan, kualitas intruksional, dan kualitas teknis semuanya sudah baik dan tidak ada revisi lagi. Sehingga dapat disimpulkan bahwa media pembelajaran berbasis aplikasi android dinyatakan valid dan layak untuk digunakan.

\section{Hasil Tahap Uji coba (Implementation)}

Media pembelajaran ini diuji cobakan kepada peserta didik kelas XI di SMA Negeri 2 Kikim Selatan Kabupaten Lahat. Uji coba selama 3 kali pertemuan yaitu pada tanggal 9-11 Juni 2021. Dalam tahapan ini ada beberapa data yang diperlukan. Seperti data angket respon peserta didik untuk mengetahui kepraktisan media dan data hasil soal tes untuk mengetahui keefektifan media pembelajaran berbasis aplikasi android. Sebelum melaksanakan uji coba kepada peserta didik, harus mempersiapkan segala sesuatu yang diperlukan seperti RPP, angket respon peserta didik, dan soal tes hasil belajar.

Pada pertemuan pertama dan kedua dilakukan proses pembelajaran sesuai dengan RPP yang telah dibuat dan menggunakan media pembelajaran berbasis aplikasi android. Selanjutnya pada pertemuan ketiga, pemberian angket respon peserta didik guna memperoleh data penilaian kepraktisan media pembelajaran. pemberian soal tes hasil belajar peserta didik hal ini untuk melihat keefektifan dari media yang telah dikembangkan.

\section{Hasil Tahap Evaluasi (Evaluation) \\ Analisis Kepraktisan}

Analisis Kepraktisan media pembelajaran berbasis aplikasi android yang dikembangkan didapatkan dari data angket respon peserta didik yang telah diisi oleh peserta didik. Data angket respon peserta didik merupakan penilaian peserta didik terhadap media pembelajaran berbasis aplikasi android. Data angket respon peserta didik digunakan untuk mengukur apakah media pembelajaran berbasis aplikasi android praktis atau tidak. Adapun hasil penilaian keparaktisan dapat dilihat pada Tabel 5. 
DOI: https://doi.org/10.24127/ajpm.v10i3.4050

Tabel 5 Hasil penilaian kepraktisan

\begin{tabular}{ccc}
\hline Aspek & $\begin{array}{c}\text { Nilai } \\
(\%)\end{array}$ & $\begin{array}{c}\text { Rata- } \\
\text { rata (\%) }\end{array}$ \\
\hline Kemenarikan media & 82,5 & 82,9 \\
$\begin{array}{c}\text { Ketertarikan siswa terhadap } \\
\text { media dan materi }\end{array}$ & 87 & \\
Motivasi & 80,4 & \\
Kemudahan & 79 & \\
\hline
\end{tabular}

Dari aspek kemenarikan media nilai $\mathrm{K}$ diperoleh $82,5 \%$ dengan kategori sangat praktis, aspek ketertarikan siswa terhadap media dan materi nilai $\mathrm{K}$ diperoleh $87 \%$ dengan kategori sangat praktis, aspek motivasi diperoleh skor $80,4 \%$ dengan kategori sangat praktis dan aspek kemudahan diperoleh skor $79 \%$ dengan kategori praktis. jika di rata-ratakan Nilai K diperoleh adalah $82,9 \%$. Sehingga media pembelajaran berbasis aplikasi android mendapatkan kriteria Sangat Praktis.

\section{Analisis Keefektifan}

Penilaian keefektifan digunakan untuk mengetahui apakah media pembelajaran berbasis aplikasi anroid yang dikembanakan efektif atau tidak. Penilaian keefektifan media pembelajaran berbasis aplikasi android dapat dilihat dari tes hasil belajar peserta didik didapat bahwa ada 19 peserta didik dari jumlah keseluruhan 20 peserta didik yang mendapatkan nilai mencapai KKM. Adapun persentas hasil tes belajar peserta didik adalah 95\%. Dengan demikian nilai $\mathrm{P}$ yang diperoleh adalah $95 \%$ sehingga media pembelajaran berbasis aplikasi android mendapat kriteria Sangat Efektif.

Berdasarkan hasil validasi oleh 4 validator yang terdiri dari 3 Dosen dan 1 Pendidik. Tahap ini merupakan tahap yang dilakukan Sebelum melakukan uji coba media pembelajaran berbasis aplikasi android kepada peserta didik. Penilaian oleh validator menggunakan angket terbuka. Kevalidan tergambar dari hasil penilaian validator (Emilya, Darmawijoyo, \& Ilma, 2011). Pada penlaian media pembelajaran berbasis aplikasi android dari ketiga aspek yang dinilai semuanya sudah baik tetapi masih ada yang harus direvisi atau diperbaiki. Kesimpulan yang dapat diambil dari penilaian keempat validator bahwa media pembelajaran berbasis aplikasi android dinyatakan valid dan layak untuk digunakan. Hal ini sejalan dengan (Rahmawati, 2014) dengan hasil penelitiannya bahwa media pembelajaran matematika basis android pada materi peluang untuk siswa SMK dinyatakan valid, praktis dan efektif untuk digunakan. Hal ini juga sesuai dengan tujuan penelitian yaitu untuk menghasilkan media pembelajaran berbasis aplikasi android yang valid.

Berdasarkan hasil uji kepraktisan media pembelajaran berbasis aplikasi android yang dilakukan dengan cara menyebar angket respon peserta didik dalam proses pembelajaran kelas yang diujicobakan yaitu kelas XI. IPS 2 SMA Negeri 2 Kikim Selatan. Dari hasil angket tersebut, diperoleh nilai $\mathrm{K}$ yang merupakan persentase nilai akhir untuk kepraktisan sebesar 82,9\%. Dengan demikian media pembelajaran berbasis aplikasi android yang telah dikembangkan dapat dikatakan sangat praktis. Hal ini sejalan dengan (Apsari \& Rizki, 2018) dengan hasil penelitiannya bahwa media pembelajaran matematika berbasis android pada materi program linear dinyatakan valid dan praktis untuk digunakan Hal ini juga sesuai dengan tujuan penelitian yaitu untuk menghasilkan media pembelajaran berbasis android yang praktis.

Berdasarkan hasil tes belajar peserta didik, dapat diketahui bahwa peserta didik yang menjadi subjek untuk ujicoba produk hanya 1 orang peserta didik yang tidak tuntas dari 20 peserta 
didik yang ada di kelas XI. IPS 2 SMA Negeri 2 Kikim Selatan. Sehingga nilai $\mathrm{P}$ yang merupakan persentase nilai akhir untuk keefektifan diperoleh sebesar 95\% yang berarti media pembelajaran berbasis aplikasi android dinyatakan sangat efektif. Hasil tersebut sesuia dengan teori yang dikemukakan oleh (Mustaqim \& Kurniawan, 2017) mengatakan bahwa kriteria pemilihan media yaitu tujuan pembelajaran, efektif, mudah diperoleh, siswa, penggunaan, tidak kaku, biaya, dan kualitas. Hal ini juga sesuai dengan tujuan penelitian yaitu untuk membuat media pembelajaran berbasis aplikasi android yang efektif.

Selama proses uji coba media, ketika belajar peserta didik yang sebelumnya tidak diperbolehkan dari pihak sekolah membawa dan menggunakan smartphone disekolah. Setelah diberi izin untuk menggunakan smartphone dalam proses pembelajaran menggunakan media pembelajaran berbasis aplikasi android antusias mereka untuk belajar sangar besar. Terlihat dari aktivitas mereka ketika belajar mereka terlihat aktif, Mereka mulai mau berdiskusi dengan teman duduk mereka, mereka bertanya jika ada yang tidak dimengerti dan bahkan mereka terlihat senang belajar menggunakan smartphone android. Hal ini meninjukkan bahwa ketergantungan generasi milenial saat ini terhadap smartphone android sangat lah tinggi. Hal ini sejalan dengan penelitian yang dilakukan oleh (Muflih, Hamzah, \& Purniawan , 2017) mengatakan bahwa terdapat hubungan yang signifikan antara pengguna smartphone dengan tingkat ketergantungan smartphone.

Dari hasil kegiatan belajar mengajar tersebut didapat kesimpulan bahwa dalam pembelajaran di sekolah sebaiknya diperbolehkan menggunkan smartphone android. Hal ini sesuai dengan penelitian yang dilakukan oleh (Nurdyansyah \& Aini, 2017) mengata-

kan bahwa peran teknologi dapat pembelajaran pada materi matematika sangat penting sebagai sumber belajar peserta didik. Sehingga peserta didik juga terus bisa update perkembangan yang terjadi terutama dibidang pendidikan. Hal ini juga sejalan dengan penelitian yang dilakukan oleh (Dewanti, Widada, \& Triyono, 2016) bahwa adanya hubungan yang positif antara keterampilan sosial dan penggunaan gedjet smartphone dengan prestasi belajar. Penggunaan smartphone bisa sangat membantu peserta didik dalam proses pembelajaran asal digunakan dengan tepat dan pengawasan dari pendidik serta orang tua.

\section{KESIMPULAN DAN SARAN}

Berdasarkan hasil penelitian dapat disimpulkan bahwa media pembelajaran berbasis aplikasi android pada materi turunan fungsi aljabar dinyatakan valid, praktis dan efektif. Hal ini berdasarkan hasil validasi oleh 4 ahli yang terdiri dari 3 dosen dan 1 pendidik layak digunakan dan dinyatakan Valid. Media pembelajaran berbasis aplikasi android yang telah dikembangkan setelah melalui uji kepraktisan dinyatakan Sangat Praktis dengan perolehan nilai K sebesar $82,9 \%$. Media pembelejaran berbasis aplikasi android yang telah dikembangkan setelah melalui uji keefektifan dan dinyatakan Sangat Efektif dengan perolehan nilai P 95\%.

Berdasarkan hasil penelitian yang telah dilakukan, sebaiknya mengembangkan media yang sama tetapi dengan materi yang berbeda agar mendapatkan media yang lebih baik. Sebaiknya juga mengembangkan bukan hanya untuk mata pelajaran matematika saja tetapi juga bisa untuk mata pelajaran lainnya. 


\section{DAFTAR PUSTAKA}

Apsari, P. N., \& Rizki, S. (2018). Media Pembelajaran Matematika Berbasis Android pada Materi Program Linear. Aksioma:Jurnal Program Studi Pendidikan Matematika, 7(1), 161-170.

Ariskasari, D., \& Pratiwi, D. D. (2019). Pengembangan Modul Matematika Berbasis Problem Solving Pada Materi Vektor. Desimal: Jurnal Matematika, 2(3), 249-258.

Ariskasari, D., \& Pratiwi, D. D. (2019). Pengembangan Modul Matematika Berbasisi Problem Solving Pada Materi Vektor. Desimal: Jurnal Matematika, 2(3).

Dewanti, T. C., Widada, \& Triyono. (2016). Hubungan Antara Keterampilan Sosial dan Pengguna Gedjet Smartphone Terhadap Pretasi Belajar Siswa SMA Negeri 9 Malang. Jurnal Kajian Bimbingan dan Konseling, 1(3), 126-131.

Emilya, D., Darmawijoyo, \& Ilma, R. (2011). Pengembangan SoalSoal Open Ended Materi Lingkaran Untuk Meningkatkan Penalaran Matematika Siswa Kelas VIII SMP Negeri 10 Palembang. Jurnal Pendidikan Matematika, 2(4), 9-18.

Firdaus, M. (2019). Pengembangan Aplikasi Math Mobile Learning Berbasis Android Pada Materi Segitiga dan Segiempat Kelas VII SMP. Universitas Muhammadiyah Mataram.

Handayani, D., \& Rahayu, D. V. (2020). Pengembangan Media Pembelajaran Interaktif Berbasis Android Menggunakan I-Spring dan APK Builder untuk Pembelajaran Matematika Kelas
X Materi Proyeksi Vektor. Jurnal Matematika dan Pendidikan Matematika, 5(1), 12-25.

Hikmah, S. N., \& Maskar, S. (2020). Pemanfaatan Aplikasi Microsoft PowerPoint pada Siswa SMP Kelas VIII dalam Pembelajaran Koordinat Kartesius. Jurnal Ilmiah Matematika Realistik, 1(1).

Karim, A., \& Savitri, D. (2020). Pengembangan Media Pembelajaran Matematika Berbasis Android di Kelas 4 Sekolah Dasar. Jurnal Lebesgue: Jurnal Ilmiah Pendidikan Matematika, Matematika dan Statistika, 1(2), 63-75.

Lubis, R. H. (2012). Peningkatan Hasil Belajar Siswa Matematika Melalui Penggunaan Media Pembelajaran Microsoft PowerPoint Pada Materi Trigonometri Siswa Kelas XI SMA N 5 Padangsidipuan. IAIN Padangsidipuan, 1-78.

Muflih, M., Hamzah, H., \& Purniawan , W. A. (2017). Penggunaan Smartphone dan Interaksi Sosial Pada Remaja di SMA N 1 Kalasan Sleman Yogyakarta. Idea Nursing Jurnal, 8(1), 1218.

Muflih, M., Hamzah, H., \& Purniawan , W. A. (2017). Penggunaan Smartphone dan Interaksi Sosial Pada Remaja di SMA Negeri 1 Kalasan Sleman Yogyakarta. Idea Nursing Journal, 8(1), 1218.

Mustaqim, I., \& Kurniawan, N. (2017). Pengembangan Media Pembelajaran Berbasis Augmented Reality. Jurnal Edukasi Elektro, 1(1), 36-48. 
Nurdyansyah, \& Aini, Q. (2017). Peran Teknologi Pendidikan Pada Materi Matematika Kelas III di MI Ma'arif Pademonegoro Sukodono. At-Thullab: Jurnal Pendidikan Guru Madrasah Ibtidaiyah, 1(1), 125-140.

Nuryatni, S. (2019). Peningkatan Hasil Belajar Matematika Materi Kesebangunan Melalui Model Pembelajaran STAD Berbantuan Media PowerPoint. Edudikara: Jurnal Pendidikan dan Pembelajaran, 4(4), 253-265.

Puji, K. M., Gulo, F., \& Ibrahim , A. R. (2014).

Pengembangan Multimedia Interaktif untuk Pembelajaran Bentuk Molekul di SMA. Jurnal Penelitian Pendidikan Kimia, 1(1).

Rahmawati, S. (2014). Pengembangan Media Pembelajaran Matematika Basis Android pada Materi Peluang untuk Siswa SMK. UIN Syarif Hidayatullah Jakarta: Fakultas Ilmu Tarbiyah dan Keguruan .

Riduwan. (2011). Skala Pengukuran Variabel-Variabel Penelitian. Bandung: CV Alfabeta.

Rohman, A. (2018). Pengembangan Media Pembelajaran Berbasis Aplikasi Android Dengan Program Adobe Flash CS 5.5 Untuk Meningkatkan Hasil Belajar Matematika Siswa SMP Kelas VII. Skripsi thesis Universitas Mercu Buana.

Siagian, M. D. (2016). Kemampuan Koneksi Matematik dalam Pembelajaran Matematika. MES: Journal of Mathematics Education and Science, 2(1), 5867.
Tegeh, M., Jampel , N., \& Pudjawan , K. (2014). Model Penelitian Pengembangan. Yogyakarta: Graha Ilmu.

Wardiyanto, M. F., \& Yundra , E. (2019). Pengembangan Trainer Kit Mikrokontroller Arduino Uno Berbasis IOT Sebagai Media Penunjang Pembelajaran pada Mata Pelajaran Sistem Kontrol Terprogram di SMK Negeri 1 Jenangan ponorogo. Jurnal Pendidikan Teknik Elektro, 8(1), 139-148.

Wedekaningsih, A., Koeswati, H. D., \& Giarti, S. (2019). Penerapan Model Discovery Learning untuk Meningkatkan Keterampilan Berpikir Kritis dan Hasil Belajar Matematika. Jurnal Basicedu, 3(1), 21-26. 